\title{
The Review of Health System of the Kingdom of Denmark and United Kingdom
}

\author{
TOTIĆ Mirza ${ }^{3}$, TOTIĆ Ibrahim ${ }^{4}$
}

\begin{abstract}
The paper deals with the functioning and development of national health systems in the Kingdom of Denmark, which is a very stable member of the European Union (EU) and United Kingdom, regardless of its recent outbreak (Brexit) from a large European family. The main goal is to make a review of the necessity of creation of professional health personnel, their mobility, financing of business processes and medical procedures, and also on general problems that the health systems are facing every day. As these are highly developed European economies, it is known that the creators of their health policies are continuously working on the improvement of health systems, ensuring adequate health care and raising and maintaining a high level of collective health for the population.

Lately, in these kingdoms, many people believe that for the proper functioning of health sector in general, the way of obtaining of necessary financial resources, their amounts and sustainability of the sources have no big importance, while as far more significant emerge the influences of globalization processes which like hurricane destroy systems (insufficient professional staff) without legal and economic-medical arrangements. Given that the authors are not fully in agreement with this statement, they pledge to the invited authorities to pay more attention on the policy of financing, human capital, its improvement and elimination of health inequality, especially in the field of primary health care.
\end{abstract}

Keywords: European Union Member States, health system, resources, human capital, mobility

JEL: P36

UDC: 336.13:614.2(489)

336.13: 614.2(410)

COBISS.SR-ID 265398028

\section{Introduction}

Each Member State of the European Union (EU) is obliged to define the strategy in order to create a high-quality national health system that will become an integral part of internationally integrated healthcare activities, and in which their citizens could easily use the adequate health care. Its formation in all Member States is mostly left to healthcare workers and associates, but also political leaders and other factors whose influence is reduced to the usual pressure, adoption of decisions that at a given moment correspond to a political establishment. Until recently it was believed that every healthcare system in the European

\footnotetext{
${ }^{3}$ University of Novi Pazar, Department of law, email: mirzatotic@yahoo.com

${ }^{4}$ State university of Novi Pazar, Department of law, email: ibrahimtotic@yahoo.com
} 
Union (EU) was hermetically closed and that its fate was exclusively in the hands of members of scientific medicine who were highly elevated above the others, so for other professions and occupations the role of outsiders was traditionally reserved (Steve Smith, John Baylis, Patricia Owens, 2014: 596).

However, this conclusion loses its weight with the consideration that various activities in many Member States of the European Union (EU), due to the influence of modern medicine, have made significant progress. This is characteristic for the Kingdom of Denmark, United Kingdom, but also for other European countries. In these countries, medicine has made a number of advanced steps: it has become a pillar of healthcare activity (it will forever remain) and a guarantee of renewable human resources from which the healthy potential can always be recruited for business needs.

In these kingdoms (but also in other European Union Member States), the health system is perceived as a social phenomenon, so the creators of their health policies use their own expert strength and various methods and patterns in order to create an appropriate scientific base and a safe haven for citizens/(Ivana Radić, Vesna Kahrimanović, Branko Budimir, 2007: 72).

When it comes to the insured, everyone talks about a man because everything is related to him in the field of healthcare activity. In this regard, the modern practice has dispelled all dilemmas by offering many arguments that tell more than any resolution, declaration or directive. One of the most convincing stands that the insured is every resident of any Member State of the European Union (EU), regardless of the fact whether it benefits health care or not, if is prepared to allocate the necessary financial resources for these purposes. Specifically, in the mentioned kingdoms the latter are being directed to financing of the needs of health service providers in order to provide new generations of medical experts that will use their own knowledge and skills, helped by modern instruments in modern medical treatments and procedures.

\section{Providing healthcare professionals and the challenge of mobility}

Healthcare workers and associates represent the most sophisticated form of capital available to every healthcare system in twenty-eight European Union Member States. Due to their knowledge, demonstration of expertise and specific skills, they are extremely admired by huge number of citizens in all Member States since they offer the highest level of confidence. (Dimitris D. Ballas, Dorling D. Ballas, Benjamin D. Hennig, 2014: 79). But, despite their proven quality, there are skeptics who think differently. They tend, although there are no solid arguments for something like that, to challenge the mentioned quality and diminish the achieved results for the reasons well-known only to them. Still, they have to reconcile themselves with defeat, because they are going against a very organized formation. Therefore, they must speak with respect and must give credits to the sector that managed to increase its human capital by $13 \%$ between 2008 and 2016, to create the possibility for opening new jobs (mostly for doctors) and to significantly increase the quality of citizen's health.

The European Center for Development of Vocational Training (CEDEFOP) foresees that 1.8 million workers will obtain new jobs by 2025 , which represents an increase of $7.8 \%$ (European Commission, 2017). This in the frame of European Union (EU) confirms the firm resolution to create conditions for reducing the unemployment rate along with the preservation and improvement of global health, and to give optimism to the generations of coming experts.

From this aspect, every activity of the professional medical staff in all forms of health care is perceived as a special mission. It is about increasing the health quality of citizens in European Union Member States and creating chances for new employment in other sectors, which is a direct contribution to economic growth and strengthening of social cohesion. The Statistical Office of the European Communities has accurately edited the data collected from 
the Member States of the European Union (EU) and from other countries and international organizations, finalizing 2015, informing the institutions that monitor the effects of Community policies in 28 European Union Member States that about 1.8 million health workers and associates were employed, which represents $8.5 \%$ of the total number of employees (Eurostat, 2017).

The main criteria for registering employees was their number per 100 thousand inhabitants.

In the German health system, there were 338 doctors per 100 thousand inhabitants. In Italy there were 233, in France 208, in United Kingdom 182, in Spain 179, etc. Only in mentioned Member States were employed about two-thirds, or $63.5 \%$ of doctors. The curiosity is that less developed Member States of the European Union (EU) like Greece, which along with Portugal, Italy and Spain makes a well-known PIGS group, had 632 doctors per 100,000 inhabitants, which was the highest in the European Union (EU). It was followed by Austria with 510, Portugal with 461, Lithuania with 434 doctors and so on. Other Member States (Luxembourg, Ireland, Slovenia, Poland and Romania) had fewer than 300 doctors per 100,000 inhabitants, with their number increasing substantially every year (Richard Saltman, Reinhard Busse, Josep Figueras, 2004: 174). In Portugal, the highest increase in the number of doctors per 100 thousand inhabitants was recorded during the period from 2010 to 2015.

In five years, it rose from 384 in 2010 to 461 in 2015 . In the observed period, the number of doctors in the Kingdom of Denmark, United Kingdom and/or France was not significantly changed.

In the last decades of XX and the first decades of XXI century, the mobility of health workers, especially doctors or specialists, came to the fore. They want to use their skills and knowledge in order to provide a better standard of living and more certain existence.

Otherwise, the mobility represents two-way and universal expert-demographic category.

Mobility in the first case represents the departure from the home state and departure of health workers in a neighboring European Union Member State. For example, leaving Italy for Austria or France, moving from Portugal to Spain or Italy, from Belgium to the Netherlands, or from France to United Kingdom or Germany. Although very important, the earnings are not the main motive of mobility because they can be equal or approximately the same as they were in the home country. However, the desired specialization, career advancement, advancement in profession, better working atmosphere, proximity of the chosen country to home country, etc., represent very strong motives for departure. In the second case, the mobility is exclusively initiated by the amount of earnings, while working conditions, career advancement or improvement, at least initially have no such a big importance. Regardless of how far the selected country is, doctors move from South to North (from Portugal to United Kingdom, from Spain to Germany or Sweden, or from Bulgaria, Romania or Cyprus to Germany and France). Regardless of the direction, mobility has significantly changed the medicalpopulation map of the European Union (EU), but it seems that this process is not completed yet. That's why mobility needs to be treated very carefully. The economists would say and lawyers would confirm that at the current moment, it is not desirable to prevent mobility, but also migrants, since the labor could appear in desired state in some future time, and then hard times will come for economic titans and bosses.

Irrespective of the direction of mobility, all doctors that want to leave their own country for certain reasons, most likely want to end up in the United States or in Canada (Ibrahim Totic, 2016: 343), countries that, along with Australia and New Zealand, have need for professional health personnel (World Health Organization, 2008). Mobility of healthcare staff is not always a good solution, although every expert has the right to his own choice which represents the greatest degree of individual freedom (Marks J. Templeton, 2012: 502). It is disastrous when health professionals go across the border and ignore the needs of their early patients. Michelin Wismar (2010, 24-30) describes the problem of departures as a drop-out: 
“... because health workers are really leaving, but many do not get job in the profession ... they end up in a lot of other activities doing jobs outside of the profession, in some other sector ... and finds that most education systems provide education to the wrong people." Mobility for a long time (Klaus Offe, 1972: 479-488), and especially during the second decade of XXI century experience the real expansion because many still hope that the Kingdom of Denmark, United Kingdom or the Netherlands and Luxembourg could be a welfare state or a replica in which they see the opportunity to fulfill their personal desires.

\section{Kingdom of Denmark}

The health system in the Kingdom of Denmark functions at a high level thanks to the model established by the Institute for Quality and Accreditation in Health, which means that the government does not have a major influence on its functioning. The role of government is quite limited given that in addition to the public, the private health sector also functions. If the government does perform certain functions, it mainly refers to regulation, coordination, offering advices and determination of the responsibility for realization of set goals.

Government bodies (Ministry of Health, Health Protection Agency, Pharmaceutical Chamber) are responsible for implementation of national health policy, regulation of national health legislation, formulation of measures and regulations, establishment of cooperation between different stakeholders in health care, provision of necessary information regarding quality of health and treatment at the patient's complaint. Since the health authority in the Kingdom of Denmark is formed as three-step (municipal or local, regional and central), it introduced the Law on Financial Stability in 2012, which gives all municipalities and regions the opportunity to keep $1.5 \%$ for the internal needs from their budgets. As for the central government, it approves the opening or the commissioning of new specialized or the closure of existing, redundant healthcare facilities and capacities (Rudolf Klein, 1985: 41-58). Public health spending in the Kingdom of Denmark in 2016 amounted to \$5,205 per capita or a very high $10,4 \%$ of gross domestic product (GDP), which ranked sixth in the European Union (EU).

In the same year, about $84 \%$ of total health expenditures were covered by budget funds, the taxes whose rate of total taxable income had been set at $8 \%$ (Elias Mossialos, Martin Wenzl, 2016: 180).

In addition to the public (state), in the Kingdom of Denmark exists also the private health insurance. In the report given by the Organization for Economic Cooperation and Development (OECD) for 2016, private spending on health care was \$ 831 per capita, or almost $1.7 \%$ of gross domestic product (GDP).

(https://data.oecd.org/denmark.htm\#profile-health, 2018). The residents of the Kingdom of Denmark under the mentioned law have the possibility of choosing between two different categories of health care. The first involves a large number of general practitioners paid for their work in a combined way, through the principal and basic fees for providing health services, similar to those in United Kingdom. Nearly 99\% of Danish residents are classified in this category. Insured persons belonging to the other group (close to 1\%) have the possibility, in addition to the GPs, to visit any specialist, in the case of need, if they are willing to participate in covering of the medical expenses incurred on the basis of their visit (Denis Protti, Tom Bowden, Ib Johansen, 2009: 17-22).

Danish inhabitants have good health, so, they are more successful in this category than residents of most other European Union (EU) countries. Many are satisfied with the quality of their health. They do not pay attention on significant income differences and asserts that residents of higher-income countries of the European Union (EU) have better health than those with lower incomes. In the Kingdom of Denmark, the duration of human life is pretty much prolonged (from 77.9 years in 2005 to 80.6 years in 2015), so older people are exposed to 
various health problems. However, the Danish healthcare system with a lot of success prevents the emergence of health disorders, which is the reason why, for example, the rate of mortality from myocardial infarction is among the lowest compared to other European Union Member States.

The influence of social behavioral factors causing certain disorders and behavioral risks is generally favorable. Tobacco consumption has experienced a sharp decline over the last ten years, which is a special success, however, Danes, both adults and adolescents, consume alcohol uncontrolled being the leading nation in the European Union (EU). This social deviation is directly related to the mortality rate which is higher in the Kingdom of Denmark than in most other European Union Member States. In general, the Danish healthcare system is well organized, technologically equipped, effective and very open to allow insured persons the unrestricted access to all forms of health care. It employs the highest number of nurses per capita in the European Union (EU). There were 294 physicians coming to 100 thousand inhabitants (Patrick Kierkegaard, 2013: 14).

The health system of the Kingdom of Denmark is not only a European, but also a world leader in the use of modern information technology. Thus, it has a first-class IT infrastructure that still needs some upgrades to be fully integrated, which promises a high degree of sectoral interoperability. High healthcare technology is currently mostly used by employees in the primary health care sector, where almost every doctor has electronic records that complement clinical functionality (Mary Stuart, Michael Weinrich, 2001: 474-480). The successful development of the Danish healthcare system was largely supported by health reforms initiated in 2007. Their aim was to unify the three-level health authorities for the benefit of future development, to ease the growth of health spending, to promote the quality of health care and to improve public health policy. Its realization almost completely succeeded.

\section{United Kingdom}

In addition to England, the National Health Service (NHS) in the United Kingdom includes also Northern Ireland, Scotland and Wales. It is also known as William Beveridge's health insurance model, since it was formally established as a match for Bismarck's model by the mentioned lord, as a social insurance and allied service report in England in 1942 (Sunday, December 26, 2010). The Beverage model is also used by Ireland, Canada, Kingdom of Denmark, Finland, Kingdom of Sweden, Italy, Spain, Portugal and Greece. In some of these countries the Beverage model is not basic, which means that there are also other forms of health insurance (Klein 1985: 41-58). United Kingdom allocates 9.9\% of its gross domestic product (GDP) to the National Health Service (NHS). Its basic characteristics are that all health activities are being financed by public (state) funds, which means, from the state budget. Also, the goal is that coverage of health care reaches $99 \%$ of the total population, to ensure free access to health services and public control of all flows of financial resources. A special curiosity is associated with Beveridge's health care system. Public (state) ownership of healthcare, therefore, land, buildings, accommodation facilities, equipment and all other contents used for the purpose of protecting human health, is dominant.

State institutions (primarily the Ministry of Health) give tasks to the National Health Service (NHS), decide on the design of a network of appropriate health capacities and prescribe measures and modes of organizing, managing and directing the health activities.

In the epicenter of the mentioned service there is a general practitioner. He is an embodiment of institution known as a home care physician. He gets awarded for his work according to the number of patients with a bonus depending on the number of provided health services. The number of employed health and non-health workers at the end of 2017 amounted to 1,187 thousand, of which 113 thousand were medical doctors and 320 thousand were nurses, 
while the rest were other qualification groups (Mark Britnell, 2015: 88). According to the same source, only one year before, in 2016, the number of employees amounted to 1,164 , of which 111 thousand were medical doctors and 319 thousand were nurses. In 2017, there was a negligible increase in the number of employed doctors by $1.02 \%$ and nurses of only $1 \%$.

Among doctors employed in the National Health Service (NHS) there is a large number of members of various nationalities, so on three doctors comes one who is obligatory the foreigner. Over 21,000 are Europeans, while the largest number of those coming outside of the continent are Indians, Pakistani, Nigerians and Egyptians. Otherwise, there were 182 doctors and 675 nurses on 100 thousand inhabitants. Multinationalism is understood as the glue that makes the health system to be harmonious community, something that strengthens its human structure and contributes to overall functional quality. In spite of the qualities characteristic for this service (known as the largest individual health care system in the world), the British media reported in 2017 that the Care Quality Commission (CQC) had provided unfavorable information: the system of the National Health Service (NHS) is too strenuous, close to the break and has very uncertain future.

The National Health Service (NHS) largely finances its activities from fees charged in accordance with the changes made in the Immigration Law from 2014.

According to the Health and Social Care Act from 2012, which came into force in April 2013, all legal residents of the United Kingdom have been granted the right to free use of all health services provided in one place. The well-known free-of-charge health care at the place of use represents the basic principles set by the government when establishing the National Health Service (NHS) in 1948.

This practically means that the right to free health care "at the place of use" has every person who has a full and legitimate status based on a registered place of residence in United Kingdom, regardless of nationality. This category of users does not include non-resident British citizens (Virginia Berridge, 2007: 22-29).

However, it must be said that the safety of citizens is threatened by the loss of health care personnel, which, according to some opinions, relates to the government's inability to fulfill its promises. Only in 2016, the number of general practitioners decreased by 1.2 thousand, which in some areas certainly aroused concerns among the insured (Denis Campbell, 2016), regardless of the fact that it is one of the largest healthcare providers in the world, but also the consumer of funds intended to protect the health of English citizens.

More than $£ 1$ billion Sterling is spent in the primary health care sector, but also in other areas of health, including patients treated in private health care facilities, private hospital care, self-financing treatment, private dental services and the supply of medicines and other medical products. Visible British economists have calculated that 4.3 thousand Sterling pounds are spent in one second for the provision of all services provided by National Health Service (NHS) employees. Since 1948, when the proposed National Health Service (NHS) was enacted, the possibility of using private health insurance, which is now used by about $8 \%$ of the population, has been established. Mostly, it represents the added amount to the sum under which health services are provided in the domain of the National Health Service (NHS), which is considered as a charge for the extended scope of their use. The United Kingdom Government has been successful in collecting general taxes and in health sector financing policy, where 2014 represents a good example since 110 billion Sterling was allocated in the budget for its functioning. The share of private health spending has been rising rapidly. During 2010, it amounted to $£ 4.1 \mathrm{bn}$ Sterling to reach a fantastic $£ 8$.7bn Sterling in 2016. This is a major problem that will continue to be faced and difficult to bear in the future by the National Health Service (National Health Service) NHS) if official British politics do not change their course and begin to regulate the system in accordance with new, more modern, and not traditional recipes of very demanding British citizens. 
For 2020 and 2021, the National Health Service (NHS) envisaged $£ 30$ billion in Sterling for financing the actions to combat behavioral incidents. The government expects these funds to be effective in the positive direction, as this would mean that the choice of measures of its policy were correct. The United Kingdom Ministry of Health is making great efforts to achieve a shift in achieving positive results in changing the behavior of its citizens. Enjoying tobacco, alcohol and narcotics, especially among young people, is at a high level.

These vices are, as everywhere in the world, complemented by the problems of psychosomatic disorders and social deviations (Matthias Wismar et al., 2011).

Officials in the United Kingdom health sector can be criticized, not to notice that these deviations are a product of an incorrect assessment of the quality of health of citizens and differences in education and income. That is why the results are unsatisfactory, even though children under 5 years of age are involved in many activities to combat social vulnerability.

Based on this fact, the Care Quality Commission (CQC) did not make a mistake while informing the public about possible sewing breaks. Namely, the Emergency Medical Assistance Center received more than 25 thousand calls per day on the number 999 in 2015, and unfortunately, none of these calls were false.

This number of calls is alarming, but at the same time it represents the best check of operator's patience which is one of the most important features in their business. Employees of the National Health Service (NHS) in the United Kingdom on a daily basis experience discomfort in the workplace in the face of harassment, abuse or direct threat from health care users (in primary health care, departments, hospitals, etc.), their relatives, but also from other citizens. During 2014, $14 \%$ of employees had some sort of bad experience with physical violence and frequent confrontations with a number of people diagnosed with psychological disorders. Only during 2014, 57.1 million receipts for antidepressants were submitted, which is more than $100 \%$ more than 10 years ago. It is disastrous that this problem is most prevalent in the category of young people, since among them out of five, one necessarily experiences anxiety or some form of depression.

\section{Conclusions}

According to its structure, the health system in each Member State of the European Union (EU) is a vital social segment whose purpose and function is best understood by active participants in the creation of its quality. Its formation, functioning and development are in the service of citizen's health, therefore, the primary premise of human value, which has no alternative. Therefore, the role of the health system is unmatched in terms of cultivating and improving of human health. Also, must be emphasized the importance of professional personnel, modern technology, characterized by medical equipment and instrumentation, which defines its correct structure and a high organization aimed at the realization of a multitude of goals, among which the preservation of human health is a goal number one. Since the healthcare system is regarded as a modern unit in which all its components function smoothly, it should be noted that as such it was initiated and formed under the influence of the programs of accelerated industrialization.

The programs have deeply rooted expectations that its higher level of development will directly contribute to health expansion, which happened before the end of XX century, when many health systems experienced a real developmental boom. This is characteristic of health care systems of Member States of the European Union (EU) that have been strenuously pursuing (many have succeeded), to accelerate national healthcare by correct health policies, to achieve material well-being, redistribution based on social needs and to lift health care to a higher level. 
It is not a good decision that many development strategies do not experience their application. It is therefore expected that the European Union (EU) expert group, which is in charge of assessing the functioning, first of all the primary health care system, will give its full contribution to the change of situation in this direction. It is currently working on identification of tools and methodology for evaluating of the achieved results, so the final report is expected by the end of 2018. The first information tells us that health expenditures in almost all European Union Member States are growing rapidly, that they are very high and their growth is not particularly important, whether the financial resources for their servicing are being secured from bills, tax collection and other fiscal (UK, Finland, Italy, Ireland) or from paying contributions to health insurance funds (Germany, France and the Benelux countries).

Avoiding medical education in Member States is not a problem of a recent date, but it's still a problem. Member States that are aware of the gravity of issue which are able to apply the import strategy of already made medical experts, do not hesitate to do so, while not paying attention to the harm they inflict on others. On the other hand, the practice is that underdeveloped countries enroll excess medical students almost to the level of hyperproduction and many of them will go on destinations where they can realize their dreams.

Their mobility will be directed on places where more money is being offered along with a greater possibility of material, career and professional advancement. Finally, over time it has been understood that the impact of European policy on determining health in Europe for a long time was insufficient. The main reason was latent belief that all actions that go in that direction have no synchronous effect with practice and therefore the desired results are missing.

However, in recent years, the formula has completely changed so its impact is stronger, and the successes are greater.

\section{REFERENCES}

1. "World Health Organization Assesses the World's Health Systems". Who. int. 8 December 2010. An Introduction to International Relations Books. 6 editions. Oxford

2. Berridge, V. (2007). "Public Health Activism." British Medical Journal 335, pp. 2229.

3. Britnell, M. (2015). In Search of the Perfect Health System. London: Palgrave.

4. Campbell, D. (editor The Guardian), Health policy (15 August 2016). "How much is the government really privatising the NHS" - via The Guardian.

5. Dimitris, B., Dimitris, D., Hennig, B. (2011). The Human Atlas of Europe. Bristol: Policy Press.

6. European Commission, State of Health in the EU: Companion Report, Chapter 4. Creating a health workforce resilient to future challenges, Luxembourg: Publications Office of the European Union, 2017.

7. Eurostat, 2017. European Commission, Eurostat regional yearbook 2017. http://ec.europa.eu/eurostat/web/products-statistical-books/-/KS-HA-17-001 (20185-8).

8. Kierkegaard, P. (2013). Health in Denmark: A Case Study. Journal of Medical Systems, December, 37 (6): p. 14.

9. Klein, R. (1985). "Why Britain's conservatives support a socialist health care system." Health Affairs $4 \# 1$ pp. 41-58.

10. Mossialos, E., Wenzl, M. (2016). 2015 International Profiles of Health Care Systems, Australia, Canada, China, Denmark, England, France, Germany, India, Israel, Italy, Japan, The Netherlands, New Zeland, Norway, Singapore, Sweden, Switzerland, and the United States, London School of Economics and Political Science, Robin Osborn and Dana Sarnak, The Commonwealth Fund, January. 
11. OECD Data, Selected indicators for Denmark:https://data.oecd.org/denmark.htm\#profile-health. 2018-4-8).

12. Offe, C. (1972) Advanced Capitalism and the Welfare State, journal: Politics and Society. Vol. 2. No 4/ pp. 479-488.

13. Protti, D., Bowden,T., Johansen,I. (2009). “Adoption of Information Technology in Primary Care Physician Offices in New Zealand and Denmark, Part 5: Final Comparisons" Informatics in Primary Care, May 17(1): pp. 17-22.

14. Radić, I., Kahrimanović, V., Budimir, B. (2007). Vodič kroz pridruživanje Evropskoj uniji, ISAC Fond Centar za međunarodne i bezbednosne poslove International and Security Affairs Centre, Beograd.

15. Saltman, R., Busse, R., Figueras, J. (2004). Social health insurance systems in Western Europe Berkshire/New York: Open University Press/McGraw-Hill.

16. Smith, S., Baylis, J., Owens, P. (2014). The Globalization of World Politics.

17. Stuart, M., Weinrich, M. (2001). "Home-and Community-Based Long-Team Care: Lessons from Denmark". Gerontologist., 41(4): pp. 474-480.

18. Sunday, (2010)., Health Matters the Beveridge Report (1942), Social Insurance and Allied Service, a.k.a.

19. Templeton, J. M. (2012). Worldwide Laws of Life, 200 Eternal Spiritual Principles, Mladinska knjiga, Beograd.

20. Totić, I. (2016). Ekonomika zdravstva, Državni univerzitet u Novom Pazaru, Novi Pazar. University Press.

21. Wismar, M. (2010). Na kraju svi odu u SAD ili Kanadu, Prva konferencija srpske medicinske dijaspore, (u: Radosavljević, G. Beograd, Glasnik, Lekarska komora Srbije, 6/2010, str. 24-30).

22. Wismar, M. et al., (2011). Cross-border health care in the European Union, Mapping and analysing practices and policies, World Health Organization 2011, on behalf of the European.

23. World Health Organization (WHO), Commission on Social Determinants of Health, 2008.

\section{Article history:}

Received 17 November 2017

Accepted 10 May 2018 